\title{
Export- és befektetésösztönzési rendszerek a visegrádi országokban - tapasztalatok és kihívások
}

\section{ANTALÓCZY KATALIN - ÉLTETŐ ANDREA}

A visegrádi országok - különösen a három kisebb - rendszerváltás utáni gazdasági stratégiájában és fejlödésében meghatározó szerepet játszottak a külföldi közvetlentőke-befektetések, a globális értékláncokba való beépülés, és az ezeken belül bonyolódó, külföldi leányvállalatok által meghatározott, EU-túlsúlyú export. A kétezres évek elsö évtizedének végétől kezdett gondot okozni e stratégia kifulladása, problémái, a változtatás szükségessége. A 2008-as gazdasági-pénzügyi válság-amely erösen sújtotta az Európai Uniót és a jármügyártást - a négy ország kivitelének zuhanásán keresztül látványosan mutatott rá exportjuk rendkivül erös szektorális, területi és vállalati koncentrációjára. A krízis csillapultával a kivitelnek még a korábbiaknál is nagyobb szerepe lett a visegrádi országok gazdasági növekedésében, miközben egyre jobban fenyeget a megrekedés az alacsony hozzáadott értékü áruk termelése és exportja szintjén (azaz a beszorulás a közepes jövedelmü országok csapdájába). A negyedik ipari forradalom idöszakában a termelési folyamatok, a munkaerőpiac várható gyökeres átalakulása eddig nem látott, további kihívások elé állitják a négy országot. A cikk bemutatja és elemzi, hogy milyen fókusszal, célokkal, intézményi változásokkal reagáltak a visegrádi országok külgazdasági stratégiái, export- és befektetésösztönzési rendszerei ezekre a kihívásokra. A stratégiák szemléletesen mutatják, hogy az egyes kormányok mit értettek meg a helyzetböl és milyen irányban mozdultak el. A gazdaságpolitikai, szabályozási reakciók az egyes országok jövöjén kívül hatással vannak az egész régió kilátásaira is, hiszen a négy

https://doi.org/10.47630/KULG.2017.61.11-12.32

Antalóczy Katalin, Budapesti Gazdasági Egyetem Külkereskedelmi Kar.

E-mail: antaloczy.katalin@uni-bge.hu

Éltető Andrea, MTA KRTK Világgazdasági Intézet. E-mail: elteto.andrea@krtk.mta.hu 
ország versenytárs a tökevonzásban, de egyben szövetséges is, mert a sikereket az egész régió versenyképessége tudja garantálni.*

Journal of Economic Literature (JEL) kód: F13, F14, P52.

A visegrádi együttmúködés alapvető célja 1991-es megalakulásakor az akkor még három ország euroatlanti integrációja volt. Az 1993-tól immár négy ország időbeli eltolódással, hangsúlybeli különbségekkel, de végső soron - hasonló gazdasági stratégiát követett. Modernizációjukat a külföldi közvetlentőke-befektetésekre (foreign direct investment, FDI) alapozták, növekedésükben az exportnak meghatározó szerepe lett. A válság előtti évtizedben gazdaságaik egyre nyitottabbá váltak. 2007-ben még a legnagyobb belső piaccal rendelkező Lengyelország esetében is az áru- és szolgáltatáskivitel a GDP közel 40 százalékát tette ki, Csehországban pedig 67, Magyarországon 78, Szlovákiában 84 százalék volt ez az arány (lásd később az 1. ábrát).

A visegrádi országok külkereskedelmének legnagyobb része a multinacionális vállalatok által irányított globális értékláncokon (global value chain, GVC) belül zajlik. A vezetö termékek elsősorban jármüipari és elektronikai cikkek, melyek legfőbb közvetlen piaca Németország, illetve az EU (Antalóczy, 2017, Damijan et al., 2013, Éltető, 2014a). A rendszerváltás után választott gazdaságfejlesztési stratégia elősegítette a négy ország gazdasági szerkezetének modernizációját, elindította felzárkózásukat. Kivitelük tehát modern és technológiaintenzív lett, ugyanakkor mára már látszanak a súlyos problémák is. Ipari és exportszerkezetük erősen koncentrált mind a vállalati, a földrajzi és az áruszerkezetet tekintve is (Grodzicky, 2014, Soós, 2015), ezért nagyon sebezhető. A hozzáadottérték-kereskedelem ${ }^{1}$ adatait elemző tanulmányok kimutatták, hogy a 90-es évek második felétől a visegrádi országok exportjában drasztikusan csökkent a hazai hozzáadott érték a magas importtartalom miatt (Antalóczy, 2017, Foster-McGregor-Stehrer, 2013, Rahman-Zhao, 2013, Stöllinger, 2016). Mindez arra utal, hogy kialakult a közepes jövedelmủ országok csapdája, vagyis a globális termelés alacsonyabb hozzáadott értékű, munkaerő-igényes fázisai dominálnak. Ezek a munkafolyamatok könnyen továbbvihetők a még alacsonyabb bérköltségủ országokba, a képesség a magasabb szintre lépésre viszont hiányzik.

* A cikk az Éltető-Antalóczy [2017] és Antalóczy-Éltető [2016] mühelytanulmány erősen átdolgozott változata, és az NKFIH 115578 számú kutatás (Az exportot befolyásoló tényezők - három európai régió összehasonlítása) keretében készült.

1 Az OECD TiVA és a WIOD hozzáadott érték kereskedelmi adatbázisai input-output táblázatokon alapulnak. A TiVA-adatok jelenleg 2011-ig, a WIOD legújabb adatai pedig 2014-ig állnak rendelkezésre. 
A világgazdasági válság a visegrádi országok (V4-ek) exportját is erőteljesen sújtotta. A 2009-es nagy kereskedelmi „összeomlás” ráirányította a figyelmet a mélyebb szerkezeti problémákra, a globális értékláncokba való jelenlegi betagozódás kockázataira is. A 2009-es zuhanás után a kivitel újra gyorsan fellendült, és a válság belső fogyasztást és beruházást visszafogó hatása miatt az export a legfontosabb növekedési tényezővé lépett elö. Cikkünkben azt vizsgáljuk, hogy a hasonló múlttal, hasonló külgazdasági stratégiával, ösztönző rendszerrel - eszközökkel és intézményekkel - rendelkező V4-ek hogyan reagáltak e kihívásokra, hogyan alakították általános gazdasági környezetüket. Elfogadtak-e - és ha igen, akkor milyen jellemzőkkel bíró - külgazdasági, általános gazdaságfejlesztési stratégiát, s ebben mire helyezték a hangsúlyt. (Fontos megjegyezni, hogy a visegrádi gazdaságok nem egységesek és egymással is versenyeznek a tőkevonzás terén, de a térség valójában együtt jelent igazi vonzerőt a befektetők számára.)

\section{A szükebb és tágabb értelemben vett ösztönzés}

A V4-országokban az export és a külföldi közvetlentőke-befektetések szoros kapcsolatban vannak, ezért a tökebefektetések ösztönzése az exportot is támogatja. Az FDI-t a fizetésimérleg-statisztikában veszik számba, a folyósítás módja alapján három részét - a részvény és egyéb tulajdonosi részesedést, az újrabefektetett jövedelmet és az egyebeket (jellemzően vállalathálózaton belüli hitelt) - megkülönböztetve. Az ösztönzés az első két komponensre irányul. A külföldi közvetlentőke-bevonás ösztönzésére alkalmazott eszközöket két nagy csoportra oszthatjuk: szükebb értelemben vett, csak a külföldi beruházásokra vonatkozó, illetve a tágabb értelemben vett, az általános befektetési klímára ható gazdaságpolitikai módszerekre (Antalóczy-Sass, 2000).

Az empirikus kutatások alapján egyértelmüen megállapitható, hogy a tágabb értelemben vett ösztönzés a meghatározó egy ország vonzereje szempontjából. Ide tartozik a jogbiztonság, a politikai és gazdasági stabilitás, a kiszámíthatóság, az adott ország általános gazdasági állapota, termelési tényezőkkel való ellátottsága, illetve a befektetésekre áttételesen ható makrogazdasági politikák (fiskális és monetáris politika, strukturális politika, munkaerőpiaci politika, oktatási-képzési politika, egészségügyi politika) (Antalóczy-Sass, 2000).

A szükebb értelemben vett befektetésösztönzők célja a befektetések kockázatának, költségeinek csökkentése, megtérülésük javítása. Eszközei közé tartoznak az 
adókedvezmények, az adómentességek, a pénzügyi szubvenciók és az egyéb támogatások (infrastruktúra-fejlesztés, technikai segítség, szolgáltatások nyújtása a beruházás megvalósítása során stb.)

$\mathrm{Az}$ előbb felsorolt tágabb értelemben vett befektetésösztönzők a vállalatok exportjára is hatnak. A kivitel esetében is beszélhetünk szűkebb értelemben vett ösztönzőkről, amelyeknek - a befektetésösztönzéshez hasonlóan - szintén széles körü szakirodalma van. Ezek az empirikus vizsgálatok, kérdőíves felmérések kapcsolatot keresnek az export növekedése és az exporttámogató intézkedések között. A szükebb értelemben vett exportösztönzők elsősorban a kis- és középvállalatokat célozzák. A kormányok ösztönözhetik a kivitelt „puha” eszközökkel, így gazdaságdiplomáciával és exportösztönző programokkal (Van Biesebroeck et al., 2016) és „keményebben”, közvetlen pénzügyi támogatással, finanszírozással, garanciavállalással. Az eszközök hatásosságáról folytatott kutatások eredményei vegyesek. Egyesek szerint van pozitív kapcsolat a „puha” ösztönzök és a kivitel között (Nitsch, 2005, Rose, 2007), bár a korreláció mértéke különbözik exportőrönként és az első külföldi képviseleteknek erősebb a szerepük, mint a később megjelenőknek. Mások (Head-Ries, 2010, Moons-van Bergeijk, 2013) úgy vélik, hogy a gazdaságdiplomácia exportra gyakorolt hatása nem egyértelmü. Az exportösztönző intézmények hatása és hasznossága ugyancsak vitatott. Néhány esetben megállapítható pozitív szerepük, más esetekben azonban hatásuk nem jelentős (lásd Durmuşoğlu és társai, 2012 irodalomáttekintését).

A „kemény” exportfinanszírozó eszközök a kivitel pénzügyi biztosítását szolgálják. Az export komplex feladat a vállalatoknak, számos politikai, gazdasági, árfolyam-, nemfizetési kockázattal kell szembenézniük (Malaket, 2014). Az állami segítség minden ilyen esetben nagyon fontos, különösen a kis- és középvállalatoknak. A magánkézben lévő exporthitel-biztosító intézmények nem mindig akarják, illetve képesek ezeket a kockázatokat kezelni. Ezért a kormányok exportot finanszírozó és garanciát vállaló állami tulajdonban lévő intézményeket alapítanak, hogy csökkentsék a kivitel kockázatait és javítsák a finanszírozási feltételeket. Eddig viszonylag kevés tanulmány született az állami exporthitel- és garanciaintézmények hatékonyságáról, de az utóbbi időben mind az elméleti, mind az empirikus vizsgálatok alapján szaporodnak a bizonyítékok az exportra gyakorolt pozitív hatásukról.

Az 1. táblázatban összefoglaltuk az ösztönző politikák eszközeit és célcsoportjait. Cikkünkben e csoportosítás alapján mutatjuk be, hasonlítjuk össze és értékeljük a V4-országok befektetésösztönzési és exporttámogatási politikájának, külgazdasági stratégiájának, eszköz- és intézményrendszerének jellemzőit, dön- 
tően a 2007-2008-as válság után. (Megemlítjük, de részletesen nem foglalkozunk az exporthitel- és garanciaügynökségekkel.)

1. táblázat

\section{Az export- és befektetésösztönzés eszközei és célcsoportja}

\begin{tabular}{|c|c|c|c|c|}
\hline \multirow[b]{2}{*}{ Cél } & \multicolumn{2}{|c|}{ Szűkebb értelemben vett ösztönzők } & \multicolumn{2}{|c|}{ Tágabb értelemben vett ösztönzök } \\
\hline & Eszköz & $\begin{array}{l}\text { Kik tudják igény- } \\
\text { be venni? }\end{array}$ & Eszköz & $\begin{array}{l}\text { Kik tudják igénybe } \\
\text { venni? }\end{array}$ \\
\hline FDI & $\begin{array}{l}\text { Pénzügyi szubven- } \\
\text { ciók } \\
\text { Adókedvezmények } \\
\text { Egyéb (különleges } \\
\text { zónák) }\end{array}$ & $\begin{array}{l}\text { Elsősorban a } \\
\text { nagyvállalatok }\end{array}$ & $\begin{array}{l}\text { Üzleti környezet, különös } \\
\text { tekintettel a fiskális és a } \\
\text { monetáris politikára, az } \\
\text { infrastruktúrára, oktatás- } \\
\text { ra, egészségügyre }\end{array}$ & Valamennyi vállalat \\
\hline Export & $\begin{array}{l}\text { „Puha” eszközök } \\
\text { Közvetlen finanszí- } \\
\text { rozás } \\
\text { Garanciavállalás }\end{array}$ & $\begin{array}{l}\text { Kis- és középvál- } \\
\text { lalatok }\end{array}$ & $\begin{array}{l}\text { Üzleti környezet } \\
\text { Fiskális és monetáris } \\
\text { politika } \\
\text { Infrastruktúra } \\
\text { Oktatás, Egészségügy }\end{array}$ & Valamennyi vállalat \\
\hline
\end{tabular}

Külgazdasági stratégiák és szükebb értelemben vett exportösztönzés a V4-országokban a válság után

Mint a bevezetésben már rámutattunk, a V4-országok rendszerváltás utáni gazdaságfejlesztési stratégiájában fontos, a három kisebb ország esetében pedig meghatározó szerepe volt az exportorientált külföldi közvetlentőke-befektetéseknek. A multinacionális vállalatok jellemzően importból exportra termelő leányvállalataikat, vagyis az értékláncok legalacsonyabb hozzáadott értékü fázisát telepítették az országokba. Mind a négy ország fö exportpiaca az Európai Unió lett, 2007-ben - tehát a válság előtt - a szlovák kivitel 87, a cseh 86, a magyar 80, a lengyel 79 százaléka az EU-ba irányult. ${ }^{2}$ Mivel a válság az uniós gazdaságokat erőteljesen sújtotta, 2009-ben a V4-országok exportja erőteljesen zuhant, euróban számolva a magyar 20, a cseh

${ }^{2}$ Lásd: http://ec.europa.eu/eurostat/tgm/refreshTableAction.do?tab=table\&plugin=1\&pcode=tet $00036 \&$ language $=$ en 
19, a szlovák 17, a lengyel pedig 16 százalékkal. ${ }^{3}$ A következő évben már mind a négy országban erőteljesen nött a kivitel, és Magyarország kivételével a 2008-as értéket is meghaladta. A belső kereslet nyomott alakulása miatt az export GDP-n belüli aránya emelkedni kezdett, gazdasági növekedésben játszott szerepe a korábbiaknál is erőteljesebbé vált. ${ }^{4}$

Új külgazdasági stratégiát nem sokkal a válság mélypontja után csak Csehországban és Magyarországon fogadtak el. A kidolgozás mindkét országban 2010-ben kezdődött, 2011-ben fogadták el és 2012-ben vezették be az új programokat. A cseh stratégiát nyilvánosan meghirdették, és elérhető az interneten is. ${ }^{5}$ A magyar stratégiát nem hozták nyilvánosságra, csak egy vitairat volt elérhető, ${ }^{6}$ mára azonban ez is lekerült a kormány internetes oldaláról. E vitairatból, sajtóközleményekből és kormányzati tisztviselők nyilatkozataiból volt megismerhető a stratégia tartalma. A felszínen több hasonlóság is van a két stratégia között, mélységük, szakmaiságuk és kidolgozottságuk azonban jelentősen különbözik. Csehországban a korábbi, a 2006 és 2010 közötti évekre vonatkozó exportstratégiára épült az új program. Ezt vizsgálták felül, módosították az új fejlemények hatására. A cseh stratégiával ellentétben a magyar nem épült, de még csak nem is hivatkozott a 2006-ban elfogadott korábbi középtávú külgazdasági stratégiára. ${ }^{7}$ A 2010-ben hivatalba lépett új kormány szakítani akart elődei célkitűzéseivel, valamint gyakorlatával, amelyet retorikájában nagyon erőteljesen hangsúlyozott. A cseh stratégia nem csak a korábbi külgazdasági programra épült, de szervesen illeszkedett a többi - versenyképességi, innovációs, külpolitikai, biztonsági - kormányzati programhoz is. A magyar esetében ilyen öszszehangolásról nem beszélhetünk. A két stratégia által kitűzött célok között több hasonló is van. Mindkettő a legfontosabb problémák között említi a multinacionális vállalatok és az Európai Unió túlsúlyát a kivitelben, így a kis- és középvállalatok exportban betöltött szerepét növelni, az Európai Unió részesedését pedig csökkenteni kívánja. A földrajzi diverzifikáció a magyar stratégiában keleti nyitásként jelenik meg, fő iránya Kína, India, Oroszország, Dél-Korea, Törökország, az ASEAN, a FÁK és az arab országok. A cseh stratégia az ekkor gyorsan növekvő ázsiai, latinamerikai országok mellett az Egyesült Államokat, Kanadát, Svájcot, Norvégiát is

\footnotetext{
${ }^{3}$ Lásd: http://ec.europa.eu/eurostat/tgm/refreshTableAction.do?tab=table\&plugin=1\&pcode=tet 00002\&language $=$ en alapján saját számítás

${ }^{4}$ Különösen Magyarország esetében volt ez így, ahol a szükséges prociklikus válságkezelés következtében a belső kereslet (fogyasztás, beruházás) zuhanása miatt az egyetlen növekedési faktor ebben az időben az export volt.

${ }^{5}$ Bővebben lásd: http://www.mpo.cz/dokument104211.html

${ }^{6}$ Lásd: http://www.kormany.hu/download/1/d7/30000/kulgazdasagi_strategia.pdf

${ }^{7}$ Lásd: http://www.nibiru.hu/880/mohu.htm
} 
megnevezi mint fontos és kívánatos célországokat. A magyar külgazdasági stratégia további három célja az exportteljesítmény növelése (2015-re 120 milliárd euróra), a tartós külgazdasági egyensúly megteremtése és a külföldi befektetések ösztönzése volt. A cseh stratégia további két célja közül az egyik ugyancsak mennyiségi volt (az exportőr kis- és közepes vállalkozások - kkv-k - számának 50 százalékos növelése 2020-ra). A másik azonban a számszerüsítettek mellett nagyon fontos minőségi továbblépést tüzött ki célul: a cseh export magasabb hozzáadott értékü, innovatív szerkezet felé történő elmozdítását, a globális értékláncokban való feljebb lépést, a szolgáltatásexport arányának növelését. A célok eléréséhez a cseh stratégia a meglévő intézményrendszer ésszerüsítését, az egyes export- és befektetésösztönző szervezetek összehangoltabb müködését rendelte hozzá. Magyarországon a külgazdasági stratégiához kapcsolódóan ezzel szemben teljesen átalakították a szervezeti rendszert és módosították a döntési szinteket. Ahogy a gazdaságpolitika más területein, így itt is fordulat történt az erős, közvetlen állami beavatkozás irányába. Módosították az egész külgazdasági stratégiához kapcsolódó intézményrendszert, majd az átalakított rendszert is többször átstrukturálták. A 2014-es választások után létrehozták a Külgazdasági és Külügyminisztériumot az akkor államtitkár, majd később miniszter szerint azért, mert „....megértették az új világ üzenetét, és a magyar külpolitika tetteinek fókuszában a nemzeti érdekek, a külgazdasági érdekek érvényesítése áll." " Ugyanebben az évben az exportösztönzés fö intézményévé a Magyar Nemzeti Kereskedőház Zrt. vált, és létrehozták a Nemzeti Befektetési Ügynökséget, amely a külföldi beruházások ösztönzését végzi. A magyar külgazdasági stratégia tehát hangsúlyozta az export fontosságát, amelynek növekedését elsősorban a piacszerkezet ún. „keleti” diverzifikálásával és a kkv-k szerepének növelésével kívánta elérni. A külföldi közvetlentőke-befektetések ösztönzését nem kapcsolta össze az export növelésével. A globális értékláncokat meg sem említette, a feljebb lépés, a magasabb hozzáadott érték szükségessége, az innováció, a kutatás-fejlesztés szerepe ugyancsak kimaradt. A célokat erős állami kontrollal, az intézményrendszer központosításával, a felülről szervezett, átláthatatlan működésű kereskedőházakkal ${ }^{9}$ és gazdaságdiplomáciai eszközökkel kívánta megvalósítani.

A másik két visegrádi ország kormánya nem reagált a válságra új külgazdasági stratégiával. Az EU piacaira a V4-ek közül a legjobban beépült Szlovákia a krízis

${ }^{8}$ Lásd: http://www.kormany.hu/hu/kulgazdasagi-es-kulugyminiszterium/hirek/hatekonyabbes-nyitottabb-lesz-a-kulgazdasagi-es-kulugyminiszterium

${ }^{9}$ E kereskedőházak némileg emlékeztetnek a szocialista külkereskedelmi vállalatokra. Ahogy azok esetében, úgy itt is nagy probléma, hogy elválasztják a termelőt a külpiactól, és hogy nem alulról szerveződtek, nem a vállalatok, hanem az állam hozta létre őket. 
mélypontján, 2009-ben csatlakozott az eurózónához, ezzel még inkább elkötelezve magát az uniós gazdasági-kereskedelmi kapcsolatok mellett. Az exportra vonatkozó kormányzati stratégia és ehhez kapcsolódó eszközrendszer a külgazdaságra szakosodott - és változatlan formában fenntartott - intézmények programjában szerepelt. ${ }^{10,11}$ A Szlovák Külügyminisztérium csak 2014-ben dolgozta ki a „Külgazdasági kapcsolatok stratégiája 2014-2020" címú anyagát az export ösztönzése érdekében, amely a korábbiakhoz hasonlóan a meglévő intézményrendszerre építve elsősorban a gazdaságdiplomácia, a kormánydelegációk, az üzleti fórumok segítségével támogatná az exportot az EU és az EU-n kívüli országokba. ${ }^{12}$

A négy visegrádi ország közül Lengyelországban a legkisebb az export szerepe, s ezt az országot érintette a legkevésbé a válság is. A szlovákhoz hasonlóan a lengyel kormány sem fogadott el új exportstratégiát és nem alakította át az exportösztönző intézményrendszert sem a válság után. A lengyel külgazdasági stratégia és intézményrendszer változása nem a válsághoz, hanem a 2015. őszi kormányváltáshoz kötődik. Az új lengyel kormány 2016-tól kezdett az intézményrendszer radikális átalakításába, amely - a magyarhoz hasonlóan - az erős központosítás, a mindent átható kormányzati irányítás és ellenőrzés irányába mozdult el. Az új lengyel stratégiai fejlesztési terv ázsiai, afrikai és amerikai országokat nevez meg, mint amelyekre az exportnak fókuszálnia kell. ${ }^{13}$

A szükebb ösztönzők szerepét nehéz mérni, de nézzük meg végül, hogyan alakult 2010 és 2016 között néhány fontos statisztikai adat fényében a visegrádi országok exportja? Mind a négy országban jelentősen emelkedett az export/GDP-mutató alapján számolt nyitottság (lásd az 1. ábrát). A legnagyobb növekedés Magyarországon történt (14,2 százalékponttal magasabb a 2016-os érték, mint a 2007-es volt), nem függetlenül az összességében alacsonyabb GDP-dinamikától. Közel azonos mértékben emelkedett Lengyelországban és Csehországban, s így Lengyelországban is átlépte az arány az 50 százalékot. A legnyitottabb ország továbbra is Szlovákia maradt úgy is, hogy itt volt a legkisebb a nyitottság növekedése.

${ }^{10}$ Lásd: http://www.sario.sk/en/exporters/export-markets

${ }^{11}$ Lásd: http://www.vlada.gov.sk/sustainable-economic-development/

${ }^{12}$ Lásd: https://spectator.sme.sk/c/20049700/ministry-prepares-six-year-strategy.html

${ }^{13}$ Lásd: https://www.mr.gov.pl/media/14873/Responsible_Development_Plan.pdf 


\section{Az áru- és szolgáltatásexport aránya a GDP-ben 2007-ben és 2016-ban a V4-országokban}

(Százalék)

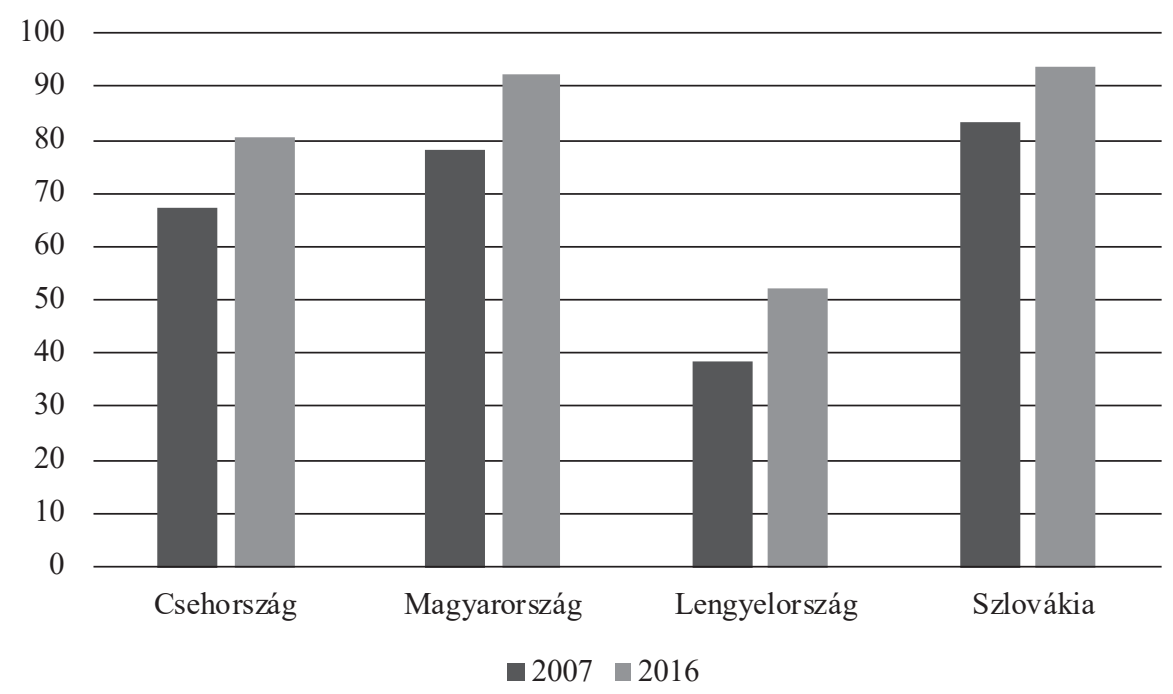

Forrás: Eurostat adatok alapján saját szerkesztés.

2010 és 2016 között az árukivitel euróban számolva Lengyelországban nőtt a legnagyobb mértékben (52 százalékkal). Csehországban és Szlovákiában ettől kissé elmaradva 47, illetve 44 százalékkal emelkedett az export, Magyarországon ugyanakkor mindössze 28 százalékos volt a bővülés. ${ }^{14} \mathrm{Az}$ erőteljes központosítás, állami beavatkozás (amely természetesen csak a kkv-k exportjára irányulhat) hozta tehát a leggyengébb eredményt. (Lásd a 2. ábrát.)

14 A mintegy 90 milliárd eurós érték pedig jelentősen elmarad a stratégia vitairatában kitűzött 120 milliárd eurós céltól. 


\section{Az áruexport alakulása 2010 és 2016 között a V4-országokban}

(Milliárd euró)

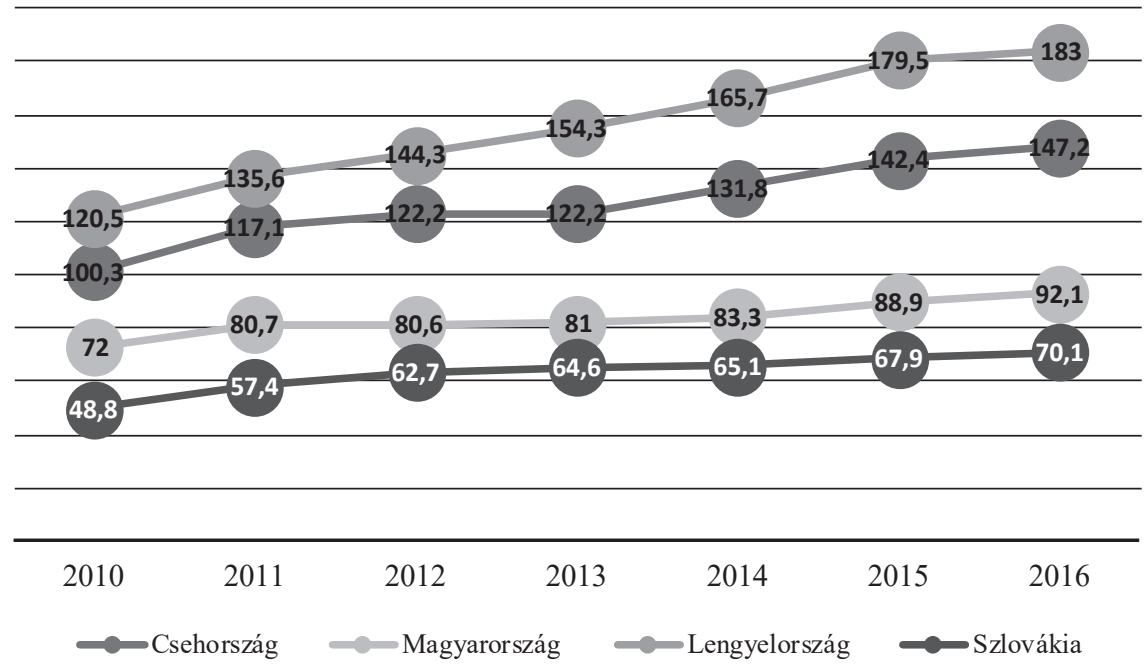

Forrás: Eurostat adatok alapján saját szerkesztés.

\section{Az Európai Unió részaránya a V4-országok áruexportjában}

(Euróalapon, százalék)

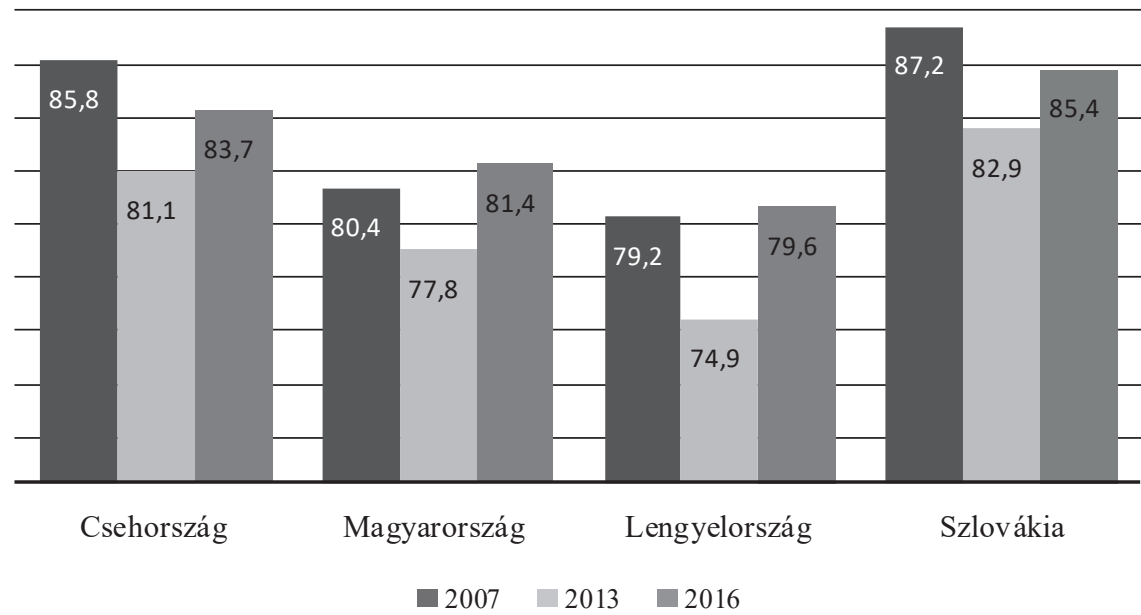

Forrás: Eurostat adatok alapján saját szerkesztés. 
Az Európai Unió részaránya a válság kitörése utáni néhány évben - az európai piacok beszükülése miatt - némileg csökkent, de nagyjából 2013-tól újra növekedésnek indult, s 2016-ban Magyarországon és Lengyelországban a válság előtti szintet is meghaladta. Három országban 80 százalék feletti az unió részesedése, és a legalacsonyabb arányt mutató lengyel exportban is megközelíti azt. Az Európai Unió részarányának csökkentését tehát a stratégiákkal nem sikerült elérni. A négy ország külkereskedelmét a globális értékláncok határozzák meg, a piacszerkezet alapvetően a láncot müködtető multinacionális vállalatok stratégiájától, és nem a kormányokétól függ. (Lásd a 3. ábrát.)

Ami a hozzáadottérték-kereskedelem alakulását illeti, 2016 novemberében jelent meg a WIOD adatbázis-frissítése 2000-2014 közötti világszintủ input-output-tábla adatokkal. Ezekből már látszanak a válság utáni trendek. Constantinescu és társai [2017] az elsők között elemezték az új adatokat, s kimutatták, hogy a 2000-2011-es erőteljes növekedés után már alig nőtt, vagy stagnált az országok globális értékláncban való részvétele. A külföldi hozzáadottérték-tartalom a kivitelben általában nem nőtt tovább. Megállapították, hogy olyan szinten van már a termelési folyamatok fragmentálódása, hogy az már alig fokozódhat. A visegrádi országokra nem végeztek számításokat, így a tendenciákat egyelőre nem ismerjük, de valószínüsíthető, hogy hasonló folyamatok lehetnek jellemzők az esetükben is.

Ha történt is némi elmozdulás a kkv-k exportarányának növekedése irányába, ${ }^{15}$ a meghatározó mind a négy országban a GVC-kben folytatott külkereskedelem. Ez határozza meg kivitelük földrajzi és termékszerkezetét is. Így a befektetésösztönzés, ennek sikeressége erőteljesen befolyásolja a külkereskedelem alakulását. Gyakran sokkal erősebben, mint a közvetlen exportösztönző intézkedések.

\section{Szűkebb értelemben vett befektetésösztönzés a V4-országokban}

Az 1990-es évek elejétől a visegrádi országok a befektetésösztönzés számos eszközét használták a multinacionális vállalatok vonzására. Az eszközök megválasztása nemzeti hatáskörben volt, módszerüket, nagyságukat az egyes kormányok határozhatták meg. Kiterjedt volt az adómentességek, az adókedvezmények köre (mint általában az a szegény országokra jellemző), és kisebb volt a direkt költségvetési támogatások szerepe. A 2004-es EU-csatlakozással az önálló befektetésöszszerepét.

${ }^{15}$ Kutatásunk további szakaszában fogjuk vizsgálni a kis- és középvállalatok exportban játszott 
tönzés lehetősége megszűnt. Az unióban a kedvezményeket állami támogatásnak számítják, amelyek nem ütközhetnek a versenyjogi szabályokba. Az Európai Unió müködéséről szóló szerződés 107. cikkelye minden olyan állami támogatást megtilt, amely torzítja az EU-n belüli versenyt. ${ }^{16} \mathrm{~A}$ csatlakozás után a visegrádi országok már nem nyújthattak a korábban megszokott módon 100 százalékos adómentességet és különböző adókedvezményeket, meg kellett szüntetni a magyarországi vámszabad területeket, továbbá a közvetlen állami támogatások rendszerének is illeszkednie kellett a közös versenypolitikai szabályokhoz. Bár a célzott szektorális támogatás tiltott, ugyanakkor a gazdaságilag elmaradott térségek támogatása nem ütközik az EU előírásaiba. Mivel a visegrádi országok számos régiójában az egy főre eső GDP elmarad az EU átlagától, így ezek az ösztönzők legálisan alkalmazhatók a beruházások támogatására is (Blauberger, 2009, Medve-Bálint, 2014) Az EU Bizottság State Aid Scoreboard címủ kiadványának adatai szerint a GDP-arányos állami támogatás Magyarországon az egyik legnagyobb az unióban. Csehország a kezdeti alacsony szintről 2015-re nagyjából elérte a magyar értéket. Az összes állami támogatáson belül a regionális támogatások aránya az uniós csatlakozás után Csehországban ugrott meg a legdrasztikusabban (Éltetö-Antalóczy, 2017). Annak ellenére, hogy a szubvenciók odaítélésénél nem lehet megkülönböztetni a beruházókat aszerint, hogy hazaiak vagy külföldiek, az uniós csatlakozás elött, de minden bizonnyal utána is a külföldi vállalatok voltak az állami támogatások legnagyobb kedvezményezettjei. Ennek az oka egyszerü, a támogatások gyakran nagy összegủ tőkebefektetéshez, illetve nagyszámú új munkahely megteremtéséhez kapcsolódnak, ezeknek az elvárásoknak pedig elsősorban a nagyvállalatok, ezen belül is a külföldi nagyvállalatok tudnak megfelelni. Az uniós irányelvek szerint támogatás adható adókedvezmény, pénzügyi szubvenció, kedvezményes kamatozású hitel és ingyenes vagy kedvezményes árú ingatlanjuttatás formájában. A regionális támogatások maximálisan adható összegénél valamennyi támogatást és a régió fejlettségét kell figyelembe venni.

Kormányzati, európai uniós források, szakcikkek alapján részletesen megvizsgáltuk a négy visegrádi ország befektetésösztönzési szabály- és eszközrendszerét, amelyből az alábbi összefoglaló következtetéseket vonhatjuk le:

A tőkevonzás céljai mind a négy országban szinte ugyanazok: az újonnan bevont, minél nagyobb tőke teremtsen új munkahelyeket (ennek ellentmondásosságára a későbbiekben még kitérünk), csökkentse a regionális egyenlőtlenségeket, hozzon innovációt. Eszközeik között sok a hasonlóság, de az alkalmazás módjában jelentős eltérések is van-

${ }^{16}$ A szerződés legutóbbi változata: http://eur-lex.europa.eu/legal-content/EN/TXT/?uri=uriserv: OJ.L_.2014.187.01.0001.01.ENG\&toc=OJ:L:2014:187:TOC 
nak. A regionális egyenlötlenségek csökkentésére stratégiai ipari övezeteket (Csehország, Szlovákia), különleges gazdasági zónákat (Lengyelország) és szabad vállalkozási zónákat (Magyarország) alkalmaznak. Ezek az övezetek arra is lehetőséget adnak, hogy a közvetlen szubvenciók mellett pótlólagos támogatást (amit gyakran nem szerepeltetnek hivatalos támogatási statisztikákban ${ }^{17}$ is lehetővé tegyenek az infrastruktúra kiépítésén, fejlesztésén keresztül. Mind a négy ország megnevez konkrét ágazatokat, tevékenységeket, amelyeket kiemelten támogat. Az innováció, a kutatás-fejlesztés, a szolgáltatóközpontok és általában a feldolgozóipar támogatása általánosnak tekinthető. Az alkalmazott pénzügyi eszközök - különböző arányban - mindenhol ugyanazok: társasági adókedvezmény, illetve adómentesség, költségvetési támogatás különböző célokra (új munkahelyek teremtéséhez, munkavállalók képzéséhez, átképzéséhez, K+F kapacitások teremtéséhez, környezetvédelmi beruházásokhoz, ingatlanvásárláshoz), helyi ingatlanadó-mentesség. A sokfajta támogatás miatt az összes nyújtott támogatás áttekintése rendkívül nehéz. A legtranszparensebb a törvénnyel szabályozott cseh rendszer, amelyben a nyújtott támogatások nagyságrendje is viszonylag jól követhetö. Az ugyancsak törvényi alapon nyugvó szlovák esetén is viszonylag átlátható a szubvenciók összértéke. Magyarországon és Lengyelországban a legkevésbé transzparens a támogatások odaítélésének mechanizmusa (egyedi alkuk, így 10 millió eurónál nagyobb befektetés esetén egyedi elbírálás, továbbá stratégiai megállapodások) és a nyúijtott szubvenciók összértéke nehezen meghatározható. Ennek ellenére a 2. táblázatban nyilvános források alapján megkíséreltük összeállítani a négy visegrádi ország kormányai által 2004 és 2017 között külföldi beruházóknak nyújtott legnagyobb állami támogatásokat. E szerint egy munkahelyre vetítve Csehország nyúitja a legmagasabb és Lengyelország a legalacsonyabb szubvenciókat (de ez adathiány miatt csalóka, lásd a táblázat alatti jegyzetet). Magyarországon a MercedesBenz kapta fajlagosan a legtöbb támogatást, az első helyezett cseh befektető ennek közel a hétszereséhez jutott. (Meg kell jegyeznünk, hogy a cseh törvény nem határozza meg a támogatások felső határát, és Csehországban a külföldi beruházásokhoz kapcsolódó minden támogatást nyilvánosan kimutatnak. Ez nem azt jelenti, hogy valóban itt a legmagasabb, csak azt, hogy itt a legátláthatóbb, legjobban megítélhető a szubvencionálás.) Szembetünő, hogy míg mind a négy országban probléma az export áruszerkezetének túlzott koncentrációja, a támogatásokban továbbra is elsősorban a jármügyártásban érdekelt vállalatok részesülnek.

17 Például az indiai Tata Group tulajdonában lévő Jaguár Land Rover az évente 150000 autót gyártó szlovákiai beruházásához a 130 millió eurós közvetlen szubvenció mellett az infrastrukturális fejlesztésekkel (vasúti pályaudvar, autóút) nagyjából további 300 millió euró támogatást kapott. Hivatalosan ez utóbbi nem a Jaguárnak, hanem az egész ipari parknak nyújtott támogatás, de mivel más nagybefektető ekkor nem érkezett, egyértelmủ, hogy a Jaguár miatt valósították meg. 


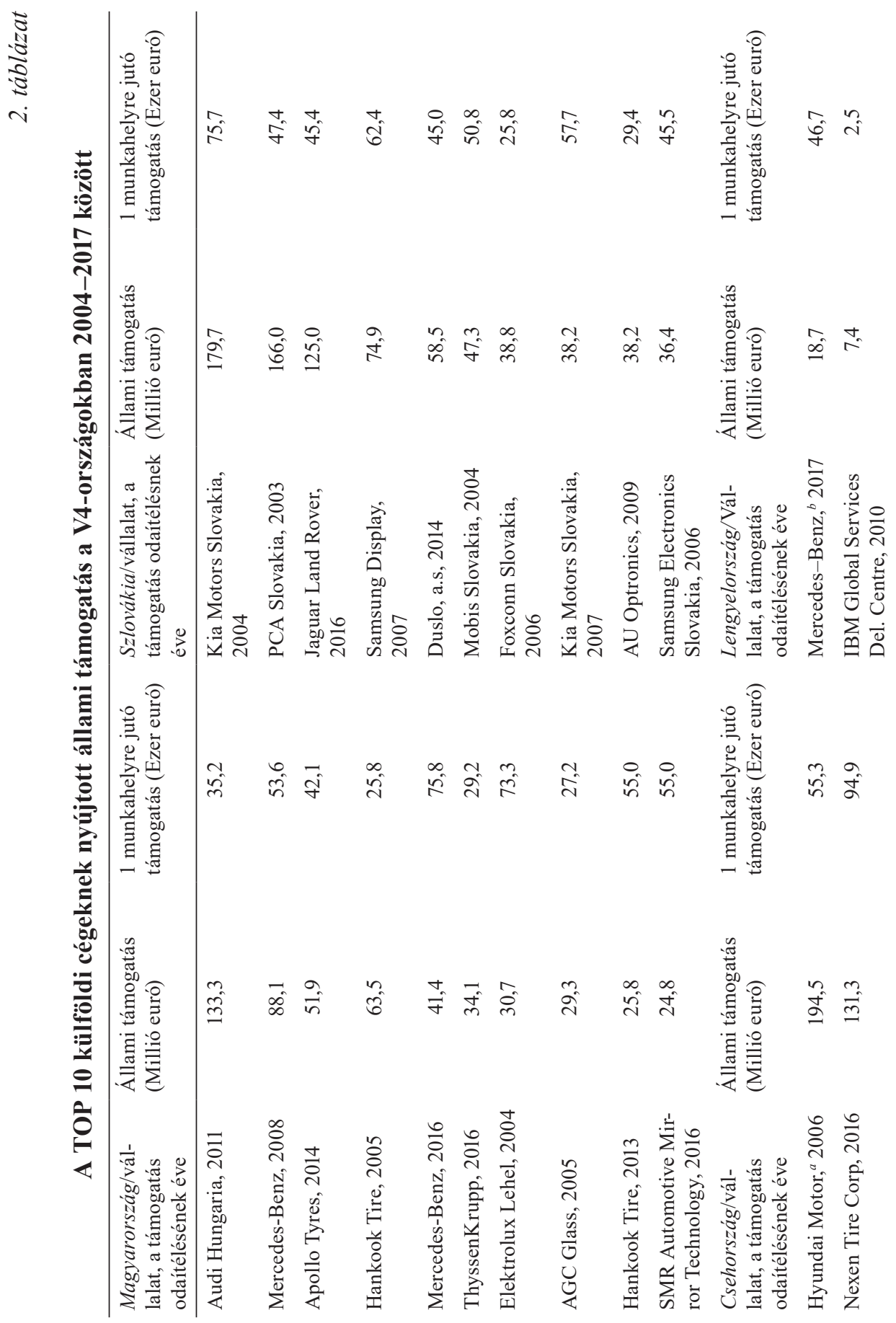




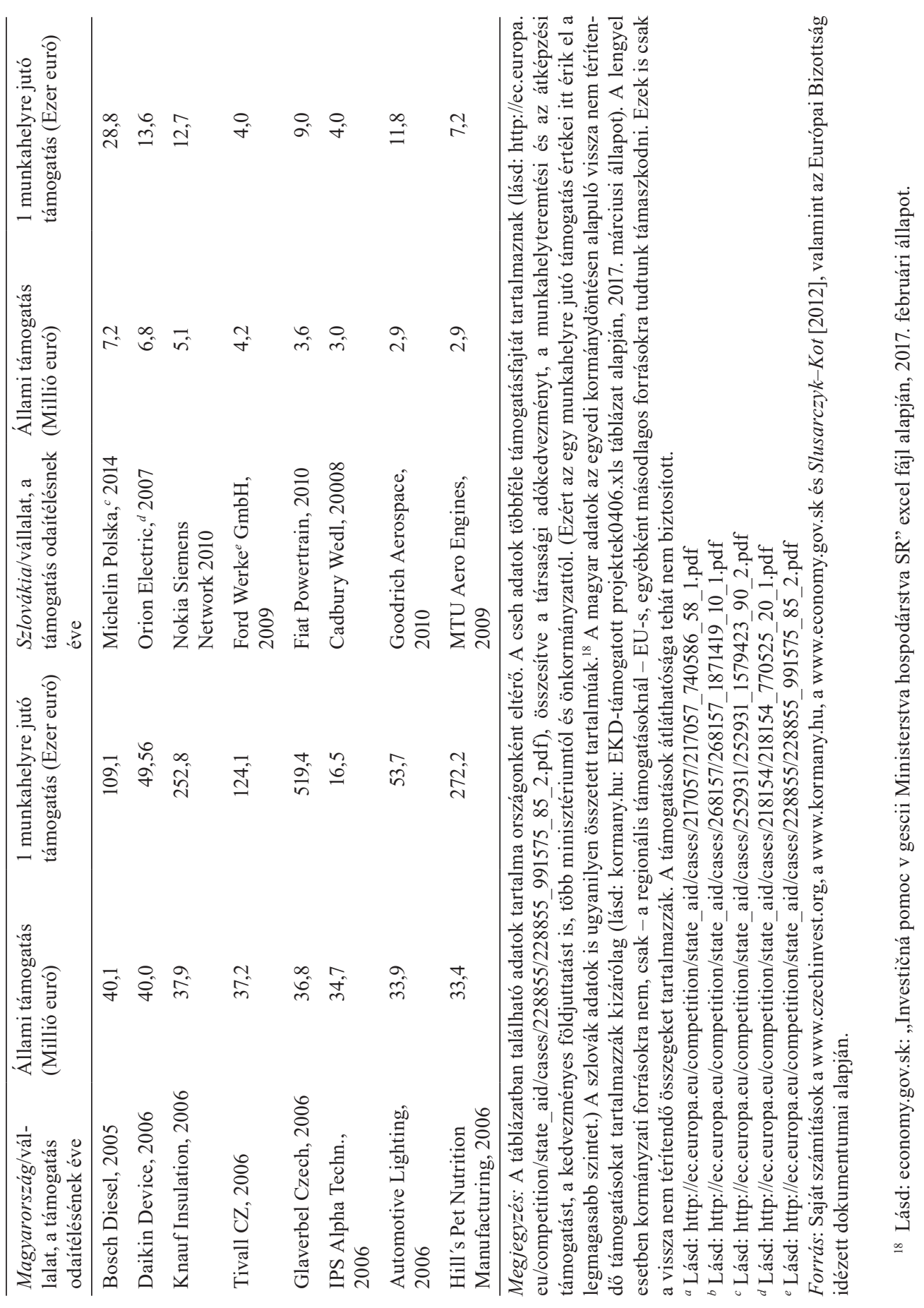


Az egyes ösztönzési rendszerek eredményességét az éves szinten országonként beáramló tőke értékének összehasonlításával kellene mérni, ez azonban a nemzeti banki FDI-statisztikákkal lehetetlen/értelmetlen. Az adatok rendkívül problémásak (lásd: Antalóczy-Sass, 2014), hiszen egyrészt a gazdaságra nem ható tőkeáramlásokat is magukban foglalják (az MNB-n kívül máshol nem, vagy alig „tisztítják” az adatokat), másrészt a valamennyire hiteles adatok megjelenése a folyamatosan szükséges korrekciók miatt 3-4 évvel későbbre csúszik.

\section{A tágabb értelemben vett export- és befektetésösztönzés a V4-országokban}

A tágabb értelemben vett befektetési és exportösztönzés ugyanazt takarja: olyan üzleti környezetet, amely kedvező a vállalatoknak, függetlenül attól, hogy hazai vagy külföldi tulajdonban vannak. Ahogy az elnevezése is mutatja, nagyon összetett, bonyolult, sokrétủ a tartalma. A jogbiztonság, a politikai és gazdasági stabilitás, a kiszámíthatóság, az adott ország általános gazdasági állapota, termelési tényezőkkel való ellátottsága, illetve a befektetésekre áttételesen ható makrogazdasági politikák (fiskális és monetáris politika, strukturális politika, munkaerőpiaci-politika, oktatási-képzési politika, egészségügyi politika) (Antalóczy-Sass, 2000, 484-485. o.) mellett ide tartozik a bürokrácia nagysága, de még a külföldiekre vonatkozó kormányzati retorika is. Valamennyi tényező áttekintése meghaladná cikkünk terjedelmét, ezért csak az általunk legaktuálisabbnak tartott elemeket emeljük ki elsősorban az Európai Bizottság 2017-es országelemzéseire támaszkodva (European Commission, 2017). ${ }^{19}$

Jogi környezet, korrupció, szabályozás

A kiszámítható jogi és gazdasági környezet az egyik legfontosabb szempont minden befektető számára, hiszen a beruházás hosszú távon megtérülő, kockázatos tevékenység. A szabályozás hitelessége, az adópolitika, a jól funkcionáló intézmények ugyancsak fontosak. Külföldi beruházó esetén a kockázatok még nagyobbak, mint belföldi vállalatok esetében, tehát ugyanazok a tényezők erősebben esnek latba.

19 Ahol nem jelezzük másként, mindenhol a Country Reports a forrás. Letölthető: https:// ec.europa.eu/info/publications/2017-european-semester-country-reports_en 
A rendszerváltás idején a kiszámítható jogi/gazdasági környezet megteremtése volt az egyik legfontosabb tényező a külföldi befektetők vonzása érdekében. A V4országokban ezt a 90-es évek közepéig (Szlovákiában a végéig) sikerült létrehozni, és hosszú évekig természetes volt létezése. Az Európai Bizottság 2017-es országjelentéseiben azonban két visegrádi ország esetében is súlyos problémák merültek fel a jogbiztonsággal kapcsolatban. A lengyel jelentés megállapítja, hogy a jogrendszer jelenlegi folyamatos fenyegetése erőteljes jogi bizonytalanságot teremt. Magyarország esetében pedig már 2010 óta alacsony és romló az intézményi rendszer minősége és a jogi, gazdasági bizonytalanság az egyik legfőbb gátja a vállalkozásnak, beruházásnak.

A kiszámíthatatlanságot, átláthatatlanságot növeli a korrupció, amely a legsúlyosabb társadalmi-gazdasági problémák közé tartozik és a beruházásokat (külföldit és hazait egyaránt) jelentősen hátráltatja. A korrupció értékelésére - bár többen vitatják tartalmát - a világon a legszélesebb körben használt korrupciós jelzőszámot, a Transparency International korrupcióérzékelési mutatóját (Corruption Perceptions Index, CPI) használjuk. ${ }^{20}$ E mutató szerint 2012 és 2016 között a korrupciós helyzet erösen romlott Magyarországon (7 ponttal) és javult Szlovákiában (6 ponttal), Csehországban (6 ponttal), valamint Lengyelországban (4 ponttal). 2016-ban a legkevésbé korrupt visegrádi ország Lengyelország volt (29. hely). Jóval lemaradva, a 47. helyen állt Csehország, az 51. helyen Szlovákia és az 57. helyen Magyarország. Az Európai Bizottság Magyarország esetében a közbeszerzések átláthatatlanságát és a verseny erős korlátozottságát tartja a legnagyobb problémának. Ugyancsak a közbeszerzés terhelt korrupcióval Szlovákiában és Csehországban, ez pedig elsősorban a kis- és közepes méretủ külföldi vállalatok beruházásait akadályozza.

A makrogazdasági környezet szempontjából nagyon fontos a fiskális politika, ezen belül a gazdasági szereplök teljes adóterhelésének alakulása. A visegrádi országokban hagyományosan Magyarországon a legnagyobb az adóterhelés. Az államháztartás teljes adó- és nem adóbevétele GDP-arányosan (centralizációs ráta) 2016-ban Magyarországon 45,5 százalékot tett ki és az 1990-es évek vége óta ez az arány gyakorlatilag stagnált. Csehországban 40,5, Szlovákiában 40 százalékos volt ez az arány és az elmúlt közel 20 évben mindkét országban enyhén emelkedett. Len-

${ }^{20}$ Az 1995-ben kialakított komplex mutató különböző független és elismert intézetek által készített szakértői felmérések korrupcióval kapcsolatos adataira épít, és a közszférában a korrupció érzékelt mértéke alapján rangsorolja a világ országait (2016-ban 176 országot). Minél alacsonyabb a mutató, annál nagyobb a korrupció az adott országban (0: nagyon erősen korrupt ország, 100: egyáltalán nem korrupt ország). Lásd: https://transparency.hu/adatok-a-korrupciorol/korrupcio-erzekelesi-index/ 
gyelországban volt a legalacsonyabb a centralizációs ráta 38,8 százalékkal, amely az utóbbi években enyhén csökkent. ${ }^{21}$

Az adópolitika megítélésében az adószintek, az egyes adónemek egymáshoz viszonyított aránya, nagysága, az adórendszer bonyolultsága, az adózók egységes kezelése (diszkriminációmentesség) és még számos jellegzetesség mellett ebben az esetben is döntő a beruházó számára a kiszámíthatóság, a tervezhetőség. Amikor egy régión belül országot választ, akkor mindezt figyelembe veszi. A V4-országok között régóta létezik adóverseny, elsősorban az adómértékek tekintetében. Szlovákia 2004ben az egykulcsos adórendszer bevezetésével jelentős előnyre tett szert a régióban. Nem csak az alacsony (19 százalékos) áfa, személyi jövedelemadó és társasági adó szintje volt vonzó, hanem az adórendszer átláthatósága, egyszerüsége is. Társadalmilag kedvezőtlen hatásait (az alacsony keresetűek adóterhének emelkedése) sokan bírálták, de az ország tőkevonzó-képességét minden bizonnyal növelte a kilenc évig változatlan formában fennálló adórendszer. 2013-tól gyakori változások kezdődtek. Választási ígéreteinek megfelelően ettől az évtől (elsősorban az államháztartás stabilizálása érdekében) az újonnan hivatalba lépő kormány a személyi jövedelemadónál bevezetett egy 25 százalékos második kulcsot (3310 euró havi jövedelem felett) és 23 százalékra emelte a társasági adót. Ez utóbbit később 22, majd 2017 elejétől 21 százalékra csökkentették. A kormány 2017-ben kiterjesztette és megemelte az ún. szabályozott ágazatokban tevékenykedő vállalatok különadóját. Meghosszabbították a 2012-ben bevezetett bankadó fizetési kötelezettségét is 2020-ig.

Magyarországon az adórendszert a magas adóterhek mellett a bonyolultság, átláthatatlanság és a gyakori változások, a kiszámíthatatlanság jellemzi. Az adórendszer az elmúlt évtizedben folyamatosan, gyakorlatilag minden évben módosult, és a változások nem az egyszerüsödés irányába mutatnak. Míg korábban leginkább az adók mértéke változott, 2011-ben az egész adószerkezetet módosította a kormány. Jelentősen - 16 százalékra - csökkentette és egykulcsossá tette a személyi jövedelemadót, 10 százalékra mérsékelte a társasági adót 500 millió forintos árbevétel alatt. Másrészt 27 százalékra emelte az általános forgalmi adót, ${ }^{22}$ és szektorális különadókat vezetett be, amelyek döntően a szolgáltatások területén (a bank- és biztosítási szektor, a telekommunikáció, a kiskereskedelem) a külföldi tulajdonban lévő vállalatokat terhelik. Ezek az adók 2016-ban a GDP mintegy 1,5 százalékát tették alapján.

${ }^{21}$ Lásd: http://www.oecd.org/eco/outlook/economic-outlook-annex-tables.htm, Annex Table 30

${ }^{22}$ Ezzel javította az adószerkezetet, hiszen jelentősen csökkent a közvetlen és nőtt a közvetett adók súlya. 
ki. 2017 elejétől a társasági adót rekordalacsonyra - 9 százalékra, vagyis már-már az adóparadicsomok szintjére - csökkentette a magyar kormány. Ez a változás döntően a nagyvállalatoknak kedvezö, és ma még erősen kérdéses, hogy (figyelembe véve a gazdasági/társadalmi környezet egyéb elemeit, de magát az adórendszert is) a változás az ország tőkevonzó-képességét növeli, vagy csak a vállalatok „adóoptimalizálását” segíti. ${ }^{23} \mathrm{Az}$ adórendszer bonyolultsága jelentős adminisztratív költségeket ró a vállalatokra, különösen a kis- és középvállalatokra. A jelentős adóterhelés egyik legfontosabb oka a társadalombiztosítási járulékok magas szintje. 2017 elejétől a kormány 5 százalékponttal csökkentette a munkáltatók által fizetendő társadalombiztosítási járulékot, és 2018-tól újabb 2 százalékpontos csökkentést tervez. Ezzel némileg csökkent az adóék, különösen az alacsonyabb jövedelmüek esetében, de még így is kiemelkedően magas (Belgium mellett a legmagasabb) ez a mutató.

Lengyelországban amellett, hogy az adóterhelés a másik három visegrádi országgal összevetve a legalacsonyabb, maga az adórendszer is viszonylag stabil volt. 2016 óta azonban az adórendszer (áfa, társasági adó) jelentős változásokon megy keresztül úgy, hogy hirtelen, egyeztetés nélkül vezetnek be módosításokat. A szabályozási környezet bizonytalanságai növekvő mértékben rontják az üzleti bizalmat. 2016-ban a gazdaságpolitika kiszámíthatatlanságát a harmadik legfontosabb akadályozó tényezőként jelölte meg a World Economic Forum 2016-os jelentése.

Csehországban az adóterhelés a második legmagasabb a V4-csoporton belül, és az adórendszer maga meglehetősen bonyolult. Nehéz az új vállalkozások piacra lépése a költséges, bonyolult és hosszú adminisztráció, a gyorsan változó jogi környezet miatt. A cseh kormány az adórendszer és az adminisztráció egyszerüsítését irányozta elő, eddig 60 intézkedést vezettek be a vállalkozásindítás költségeinek és engedélyezési idejének csökkentése érdekében. Az Európai Bizottság szerint a cseh üzleti környezetet még mindig erős szabályozási akadályok és számos adminisztratív korlát jellemzi, de elismeri, hogy az utóbbi időben számos egyszerủsítési lépést vezettek be.

Oktatás, képzés

A megfelelő mennyiségben és minőségben rendelkezésre álló munkaerő egy ország gazdasági növekedésének, versenyképességének kulcsfontosságú tényezője.

${ }^{23}$ Régebben létező speciális szabályozási elemek miatt Magyarországon egyébként is jelentős méreteket ölt a külföldi vállalatok adóoptimalizálása, amely a fizetési mérleg külföldi közvetlentőkebefektetéseket regisztráló adataiban mutatkozik meg. Bővebben lásd: Antalóczy-Sass [2014]. 
Versenyképes, dinamikusan növekvő gazdaság eleve vonzóbb a befektetők számára, de konkrét beruházási döntések meghozatalakor is döntő tényező, hogy van-e elég megfelelően képzett szakember. ${ }^{24}$ A GVC-kben való feljebb lépéshez még inkább elengedhetetlen a minőségében javuló, egyre bonyolultabb feladatokat elvégezni képes szakemberek jelenléte. A hatalmas változások (ipar 4.0), a mesterséges intelligencia, a digitalizáció, a robotizáció egyébként is teljesen átalakítják a munkakörnyezetet, amire az oktatási rendszereknek már most reagálniuk kell/ene. Így az emberi tőkébe való befektetés, vagyis többek között az oktatási rendszer a tágabb értelemben vett befektetésösztönzési eszközök egyik legfontosabbika. A visegrádi országok oktatási rendszereinek értékelését az alábbiakban alapvetően az Európai Bizottság országjelentései, az OECD PISA-felmérése és az egyes országokban müködő kereskedelmi kamarák jelentései alapján végezzük el.

A legfrissebb, 2015-ös PISA-felmérés szerint a V4-országok közül egyedül a lengyel tanulók eredményei haladták meg mindhárom területen az OECD-átlagot. Tendenciáját tekintve is pozitívak a lengyel folyamatok, hiszen 2006-hoz képest javultak az eredmények a matematika és az olvasás, és szinten maradtak a természettudományok területén. A második legjobb teljesítményt Csehország nyújtotta, az OECDátlag körül szerepeltek a cseh diákok a természettudományok és a matematika területén (de 2006-hoz képest romlottak az eredmények), és az alatt az olvasásban (itt stagnálás volt megfigyelhető). A szlovák és a magyar tanulók teljesítménye mindhárom területen elmaradt az OECD-átlag tól, és tendenciájában is romlott 2006-hoz képest. Az Európai Bizottság Magyarországról szóló jelentése megjegyzi, hogy nálunk a legerősebb az EU-ban a tanulók társadalmi-gazdasági helyzetének hatása az oktatási eredményekre. A halmozottan hátrányos helyzetủ gyermekek leszakadása, kikerülésük a normál oktatási rendszerből (szegregáció) az eredmények végletes szétszakadását, s így az átlagos teljesítmény alacsony színvonalát okozzák.

A szakképzés területén is a lengyel eredmények a legjobbak, nyilván nem függetlenül az alapképzés sikereitől. Csehországban - bár a munkaadók egy része kritizálja a szakképzés munkaerőpiaci hasznosíthatóságát - a szakképzésben résztvevők foglalkoztatottsági adatai a rendszer viszonylagos sikerességét mutatják. Szlovákiában - az Európai Bizottság elemzése szerint - az oktatási rendszer nagyon gyengén reagál a munkaerőpiaci igényekre, s ez a szakképzett munkaerő hiányához vezet és visszaveti a foglalkoztatottságot. Magyarországon ugyancsak problémák vannak a

${ }^{24}$ A rendelkezésre álló munkaerő mennyiségének és minőségének alakulását számos tényező befolyásolja, a probléma nagyon összetett. Valamennyi elemének - például a kivándorlásnak, a közmunka intézményének - a bemutatása meghaladja cikkünk terjedelmét. 
szakképzésben részt vevő tanulók kompetenciáival és tudásával, és egyre nagyobb gond a szakképzett munkaerő hiánya. ${ }^{25}$ A 2017 közepén az Európai Bizottság által közzétett gazdasági hangulatindex egyik komponense szerint ${ }^{26}$ a feldolgozóipari vállalatoknak már több mint 80 százaléka panaszkodott arra, hogy a munkaerőhiány korlátozza termelésük bővítését. Ez 10 százalékponttal magasabb, mint egy évvel korábban volt, és messze a legmagasabb - általában kétszer akkora - arány a visegrádi országok között. A korai iskolaelhagyók aránya is Lengyelországban a legalacsonyabb (2016-ban 5,2 százalék), és Magyarországon a legmagasabb, 12,4 százalék. ${ }^{27}$ Az Európa 202010 százalékos célkitüzését egyedül Magyarország nem teljesíti a visegrádi országok közül.

A felsőoktatásra vonatkozóan az Európa 2020 célkitüzése, hogy a 30-34 éves korosztály legalább 40 százaléka vegyen részt felsőfokú képzésben. A célt Lengyelország már most túlteljesítette (44,6 százalék), a másik három ország azonban jelentősen alatta és nagyjából egy szinten van (Magyarország és Csehország 33, Szlovákia 31,5 százalék. $)^{28}$

Napjainkban mind a négy országban átalakítások történnek az oktatási rendszerben. Lengyelországban - ahol minden vizsgálat szerint az 1999-ben bevezetett, kormányokon átívelö, konszenzusos oktatási reform áll az eredmények mögött - 2017től a 2015-ben hivatalba lépett kormány fokozatosan meg akarja szüntetni az ún. „alsó középiskolákat”, ${ }^{29}$ ezzel gyakorlatilag visszatérve az 1999 előtti rendszerhez.

25 2016-ban a szakképzés átalakítása során átnevezték a szakközépiskolákat szakgimnáziumokká, a képzés tartalmában azonban az új névvel éppen ellenkező irányú változtatásokat vezettek be: azoknak a közismereti tárgyaknak az óraszámát csökkentették, amelyek a munkaeröpiacon a hosszú távú sikereket, az új kihívásokhoz való alkalmazkodóképességet biztosíthatnák. A természettudományos tárgyak óraszámának csökkentése pedig várhatóan tovább növeli a magyar tanulók lemaradását a természettudományos ismeretek területén.

26 Idézi: http://www.portfolio.hu/gazdasag/munkaugy/iszonyatos_bajban_van_a_magyar_ ipar.4.257929.html

27 Lásd: http://ec.europa.eu/eurostat/tgm/table.do?tab=table\&init=1\&language=en\&pcode=t202 0_40\&plugin=1

${ }^{28}$ Lásd: http://ec.europa.eu/eurostat/tgm/table.do?tab=table\&init=1\&language=en $\&$ pcode=t202 $0 \_41 \&$ plugin $=1$

${ }^{29}$ Lengyelországban az oktatási reform keretében bevezették a mindenki számára kötelező kilenc évfolyamos alapképzést, amely 3-szor 3 évre oszlik. Ez azt jelenti, hogy 16 éves korig minden gyerek egységes képzésben részesül, s csak ezután kell arról dönteni, hogy melyik felső középiskola-típusban, líceumban (3 év, a magyar gimnáziumnak megfelelö), specializált líceumban (3 év, a magyar szakközépiskolához, majd szakgimnáziumhoz hasonló), technikumban (4 év) vagy szakiskolában tanul tovább a gyerek. Az első hat év lehetővé teszi, hogy a tanulók megalapozott, magabiztos alaptudást szerezzenek, majd az utolsó három év (amely az ún. alsó középiskola) széles körü tantárgyi kínálatával segítséget nyújt a gyerekeknek abban, hogy felmérjék saját képességeiket, érdeklődésüket, és ennek alapján (tehát csak 16 évesen) döntsenek arról, melyik felső középiskola-típusban folytassák tanul- 
Az általános rendszerből való korábbi kikerülés többek között azzal a veszéllyel jár, hogy a leghátrányosabb helyzetủ gyerekek számolási és olvasási tudása jelentősen romolhat. Az iskolarendszer szerkezeti megváltoztatásának pedig hosszú távú romboló hatása lehet. Magyarországon a kormány határozott szándéka, hogy csökkentse a gimnáziumban tanulók arányát (többek között központi felvételi rendszer bevezetését tervezik) és növelje a szakképzésben résztvevők részesedését, ahol azonban a képzés színvonala és szerkezete egyértelmüen kedvezőtlen irányban változik. A gimnazisták arányának csökkenése és a szakgimnáziumokban tanulók ismereteinek szegényesebbé válása a felsőoktatásban résztvevők számának csökkenéséhez vezet ami az Európa 2020 célkitủzésének is ellentmond. Ehhez még hozzájárul, hogy a felsőoktatás bizonyos területein szinte kizárólag költségtérítéses formában lehet tanulni, és a kormány szándékai szerint hamarosan már csak nyelvvizsgával rendelkezők juthatnak be a felsőoktatási intézményekbe. Mindezek egyértelmúen a társadalmi mobilitás csökkenéséhez vezetnek, a szegényebb, hátrányos helyzetü családokból származó gyerekek kiszorulnak a felsőoktatásból, és a szakképzésben pedig nem kapnak olyan tudást, amely a hosszú távú sikeres munkaerópiaci részvételt biztosítja a rendkívül gyorsan változó világban. A duális képzés bevezetése a felsőoktatásban közelebb hozza egymáshoz a vállalatokat és az egyetemeket, és pozitív hatással lehet a gyakorlatban hasznosítható tudás megszerzésére.

Szlovákiában ugyancsak bevezették a duális képzést a szakoktatásban, de a potenciális résztvevők érdeklődése egyelőre korlátozott maradt. ${ }^{30}$ Nincs válasz továbbá arra, hogy a halmozottan hátrányos helyzetủ, jellemzően roma tanulók szegregált oktatását hogyan kellene csökkenteni, s bevonni öket a normális (nem speciális) iskolai oktatásba. Csehországban a reform fő célja éppen az, hogy a speciális igényü gyermekek mind nagyobb számban a normál oktatási rendszerben vegyenek részt.

Az oktatási, képzési problémák már komoly munkaerőhiányhoz vezettek és további gondokat okoznak majd. A legrosszabb a helyzet Szlovákiában és Magyarországon. Mindkét országban súlyos területi egyenlőtlenségek is jellemzik a munkaerőpiacot. Bizonyos régiókban abszolút hiány van, míg máshol - éppen azokon a területeken, ahová a kormányok a befektetéseket vonzani akarják - van munkaerő,

mányaikat. (https://www.oktatas.hu/kozneveles/projektek/tamop3110_oktatasiranyitas/projekthirek/ lengyel_oktatasi_reformok)

${ }^{30}$ A Szlovák Autóipari Beszállítói Kérdőívre válaszolók 3/5-e állította, hogy részvételüket a duális képzésben hátráltatja a belső források - például a megfelelő szakanyagok és szaktanárok - hiánya. A vállalatok nem bíznak abban, hogy a duális képzésben végzettek a vállalatnál fognak maradni. Még az optimisták is úgy vélik, hogy a javulás 3 éven belül nem lesz tapasztalható. (Automotive Suppliers Survey, Slovakia 2015. Letölthetö: https://www.pwc.com/sk/en/odvetvia/automobilovy-priemysel/assets/automotive-suppliers-survey-2015.pdf) 
de tudása nem teszi alkalmassá a minőségi munka végzésére, legfeljebb a közmunkára. Ahhoz tehát, hogy a beruházók a hátrányos helyzetủ régiókba (a szabad vállalkozási övezetekbe) települjenek, nem elég a magasabb támogatásintenzitás, az infrastruktúra kialakításához és a munkahelyteremtéshez nyújtott szubvenció, hanem a megfelelő képzettségü munkaerőről is gondoskodni kell. Szlovákiában az autóipari beszállító cégek kétharmada arra számít, hogy több mint 10 százalékkal bővítenie kell foglalkoztatását, viszont négyötödük szerint a munkaerő minősége súlyosan korlátozó probléma. A munkaerőhiány felnyomja a béreket, főleg az autóipari szektorban (a Jaguár gyár érkezésének hírére a KIA és a PSA automatikusan megemelte béreit). ${ }^{31}$ Ez nem baj, ha ezzel párhuzamosan a munkaerő termelékenysége is nö, illetve képes magasabb színvonalú, magasabb hozzáadott értékủ munka elvégzésére. A német-szlovák kamara felmérése szerint az elmúlt három évben a német befektetők elégedettsége leginkább a szakképzett munkaerővel kapcsolatban romlott. ${ }^{32} \mathrm{Ez}$ a romlás még nagyobb Magyarország esetében. ${ }^{33}$ Mivel a felmérés minden országban évente elkészül, így folyamatosan képet kaphatunk a helyzet alakulásáról. ${ }^{34}$

\section{Összegzés, következtetések}

A rendszerváltás után gazdasági stratégiájukat a külföldi közvetlentőke-befektetésekre alapozó, az európai gazdaságba mélyen beépülő visegrádi országok a válság után még nyitottabbak lettek, az export gazdasági növekedésben játszott szerepe tovább nőtt. A V4-ek külgazdasági kapcsolatai a globális értékláncokba épülve határozódnak meg: a betelepült multinacionális vállalatok ágazati hovatartozása, a termelési szakasz jellemzője, a vállalatok kapcsolatai más országokban müködő leányvállalatokkal és beszállítókkal jelennek meg az export és az import statisztikai mutatószámaiban: a földrajzi és áruszerkezetben, a vállalati és termékkoncentrációban, a helyi hozzáadott érték alakulásában. A globális értékláncokba való beépülés

31 Lásd: http://www.kisalfold.hu/kulfold_hirek/jol_jarnak_a_szlovak_autogyarakban_ dolgozok_a_jaguar_land_rover_erkezesevel/2512399/

32 Lásd: http://www.dsihk.sk/fileadmin/ahk_slowakei/Dokumente/Presse/Ergebnisse_Konjunkturumfrage_2017.pdf

33 A Mercedes gyár igazgatója elismerte, hogy a magyar autóipar legégetőbb problémája a munkaerőhiány, és a Mercedes gyár bővítése 2500 munkahelyet kíván. Az oktatás kulcsfontosságú, ezért a multinacionális cég egy új oktatási centrum megnyitását tervezi 2018 szeptemberéig. Lásd: http:// www.portfolio.hu/vallalatok/cegauto/itt_az_ujabb_rekord_mindent_kipreseltek_a_kecskemeti_mercedes-gyarbol.248887.html

${ }^{34}$ A legutóbbi felmérés eredményeiről részletesen lásd: Éltető-Antalóczy [2017]. 
Export- és befektetésösztönzési rendszerek a visegrádi országokban...

a rendszerváltás után segítette a V4-országokat a felzárkózásban, a 2000-es évek második harmadára azonban már kiütköztek e gazdasági fejlődési út problémái is. A gondokat a válság felszínre hozta és különböző mélységgel, szakmai megalapozottsággal és hangsúlyokkal mind a négy országban megfogalmazták a külgazdasági és egyéb stratégiákban. Az elérendő célok között mindenhol szerepelt a kis- és középvállalatok kivitelben játszott szerepének növelése, és különböző hangsúlyokkal az export földrajzi diverzifikációja. Az elmúlt néhány évben azonban éppen hogy tovább nőtt az EU részaránya, a négy ország a multinacionális vállalatok által kiépített munkamegosztási rendszer következtében az unió kereskedelmébe leginkább beépült tagországok között maradt. ${ }^{35}$ Becslésünk szerint a kis- és középvállalatok szerepe sem nőtt, s a termékkoncentráció sem oldódott. Ezek azonban felszíni problémák. Az átalakuló (világ)gazdasági helyzet, az ipari forradalom 4.0 és a változó belső társadalmi-gazdasági tendenciák új kihívások elé állítják a visegrádi országok gazdaságpolitikáját, ezen belül külgazdasági stratégiájukat, befektetésösztönzési rendszerüket. Az értéklánc legalacsonyabb hozzáadott értékü, termelési szakaszában való megrekedés, e modell kifulladása, a továbblépésre való esetleges képtelenség jelenti a fő gondot. A helyzet és a kilátások már ma sem ugyanazok a visegrádi országokban.

Cikkünkben megvizsgáltuk a visegrádi kormányok szükebb és tágabb külgazdasági ösztönzőrendszerét. Az általános, tágabb értelemben vett ösztönzőket, jogi, gazdasági környezetet tekintve Lengyelország az elmúlt évig kiemelkedően jó teljesítményt nyújtott (alacsony korrupció, folyamatosan javuló, OECD-átlag feletti oktatási teljesítmény, alacsony adóterhelés, kiszámítható környezet, elegendő munkaerő). Ebben indult el egy visszarendeződés, vált bizonytalanná a helyzet. Csehországban az üzleti feltételek szintén viszonylag kedvezőnek bizonyultak. Szlovákiában és Magyarországon erősödött a korrupció, Magyarországon nőtt a jogbizonytalanság is (ami meghatározó egy ország befektetési vonzereje szempontjából), és az adóterhek - bizonyos területeken különösen - magasak. A szűkebb értelemben vett befektetésösztönzők azt mutatják, hogy a munkahelyteremtés a legfontosabb cél, a jármúgyártás pedig prioritás, ugyanakkor az oktatási-képzési rendszer problémái és a kivándorlás miatt komoly szakképzett munkaerő-hiány alakult ki. A munkaeröhiány következtében megemelkedő bérek miatt csökkenni kezd a V4-országok bérelőnye. Ez nem lenne gond, ha a munkaintenzív fázisok felől a tudásintenzív termelési szakaszok felé tolódna a hangsúly. Ezt viszont az oktatási rendszer - a

${ }^{35}$ Annak ellenére így van ez, hogy a statisztikai elszámolásban uniós exportként szereplő köztes termékek sok esetben - ezt vállalati interjúkból tudjuk - nem is az EU-országok piacaira kerülnek. 
szlovák és a magyar esetben súlyos - gondjai nem teszik lehetővé. Minderre csak komplex helyzetértékeléssel és társadalmi-gazdasági programmal lehetne sikeresen reagálni. Az új export- és befektetésösztönzési programoknak mindezeket figyelembe kell venniük, ha sikereket akarnak elérni.

\section{Irodalomjegyzék}

Antalóczy Katalin [2017]: Magyarország a globális értékláncokban - az áruforgalmi háló. Prosperitas, IV. évf., 1. sz., 7-41. o.

Antalóczy Katalin - Éltető Andrea [2016]: Post-crisis foreign trade trends and policies on the periphery of the European Union - comparison of the Iberian, Baltic and Central European region. Centre for Economic and Regional Studies HAS Institute of World Economics, Working Paper, No. 224. Letölthetö: http://www.vki.hu/files/download_1000.html

Antalóczy Katalin - Sass Magdolna [2000]: Müködőtőke-áramlások, befektetői motivációk és befektetésösztönzés a világgazdaságban és Magyarországon. Közgazdasági Szemle, XLVII. évf., 5. sz., 473-496. o.

Antalóczy Katalin - Sass Magdolna [2014]: Tükör által homályosan. A külföldi közvetlentőkebefektetések statisztikai adatainak tartalmáról. Külgazdaság, 58. évf., 7-8. sz., 30-57. o.

Automotive Suppliers Survey Slovakia [2016]: PricewaterhouseCoopers (PwC), Automotive Industry Association of the SR (ZAP), Slovak Automotive Institute (SAI). Letölthetö: www.pwc.com/sk/ automotive

Blauberger, M. [2009]: Compliance with rules of negative integration: European state aid control in the new member states. Journal of European Public Policy, Vol. 16., No. 7., 1030-1046. o.

Constantinescu, C. - Mattoo, A. - Ruta, M. [2017]: Trade Developments in 2016: Policy Uncertainty Weighs on World Trade. Global Trade Watch. World Bank, Washington, D. C.

Damijan, J. - Kostevc, C. - Rojec, M. [2013]: Global Supply Chains at Work in Central and Eastern European Countries: Impact of FDI on Export Restructuring and Productivity Growth. World Bank, Washington, D. C.

Durmuşoğlu, S. - Apfelthalter, G. - Nayir, D. Z. - Alvarez, R. - Mughan, T. [2012]: The Effect of Government-Designed Export Promotion Service Use on Small and Medium-Sized Enterprise Goal Achievement: A Multidimensional View of Export Performance. Industrial Marketing Management, 41., 680-691. o.

European Commission [2017]: European Semester Country Reports: Poland, Hungary, Slovakia, Czech Republic. Letölthető: https://ec.europa.eu/info/publications/2017-european-semester-countryreports_en

European Commission [2017]: State Aid Scorboard 2016. Letölthető: http://ec.europa.eu/competition/ state_aid/scoreboard/index_en.html

Éltető Andrea [2014a]: A visegrádi országok kereskedelme Ázsiával - a globális termelés lenyomata. Közgazdasági Szemle, LXI. évf., 5. sz., 586-608. o.

Éltetö, A. [2014b]: Foreign Trade Trends in the EU10 Countries. In: Éltető, A. (ed): Mind the Gap. Integration Experiences of the Ten Central and Eastern European Countries. Centre for Economic and Regional Studies of the Hungarian Academy of Sciences Institute of World Economics, Budapest, 47-68. o. Letölthetö: http://www.vki.hu/files/download_855.html

Éltetö, A. - Antalóczy, K. [2017]: FDI Promotion of the Visegrád countries in the era of global value chains. Centre for Economic and Regional Studies HAS Institute of World Economics, Budapest, Working Paper, No. 229. Letölthetö: http://www.vki.hu/files/download_1048.html 
Foster-McGregor, N. - Stehrer, R. [2013]: Value Added Content of Trade: A Comprehensive Approach. Economic Letters, Vol. 120., Issue 2., 354-357. o.

Götz, M. [2016]: Stylised Facts and Salient Features in (Post)Crisis FDI Policies in the EU. Akademia Finansów i Biznesu Vistula, Warszawa, szeptember.

Grodzicky, M. J. [2014]: Global Value Chain and Competitiveness of V4 Economies. Jagiellonian University, Institute of Economics and Management, 13-31. o.

Guidote, M. B. [2008]: Case Study on the Car Industry of the Czech Republic. Tracing FDI Trends in Central and Eastern Europe after the 1990s'. Letölthetö: www.geography.upol.cz

Gwosdz, K. - Jarczewski, W. - Huculak, M. - Wiederman, K. [2008]: Polish Special Economic Zones: Idea Versus Practice. Environment and Planning C: Government and Policy, Vol. 26., Issue 4., 824-840. o.

Head, K. - Ries, J. [2010]: Do Trade Missions Increase Trade? Canadian Journal of Economics, Vol. 43., No. 3., 754-775. o.

Malaket, A. R. [2014]: Financing Trade and Internationald Supply Chains. Gower, England, Ashgate, USA.

Medve-Bálint, Gergö [2014]: The Role of the EU in Shaping FDI Flows to East Central Europe. Journal of Common Market Studies, Vol. 52., No. 1., 35-51. o.

Moons, S. J. V. - Van Bergeijk, P. A. G. [2013]: Economic Diplomacy Works: A Meta-Analysis of its Effect on International Economic Flows. Prepared for MAER Colloquium. Erasmus University, Institute of Social Studies, The Hague, 28 o.

Nitsch, V. [2005]: State Visits and International Trade. CESifo Working Paper, No. 1582.

Rahman, J. - Zhao, T. [2013]: Export Performance in Europe: What Do We Know from Supply Links? IMF Working Paper, 13/62, International Monetary Fund.

Rose, A. K. [2007]: The Foreign Service and Foreign Trade: Embassies as Export Promotion. The World Economy, Blackwell Publishing, Vol. 30., No. 1., 22-38. o.

Ślusarczyk, B. - Kot, S. [2012]: Polish Government Impact on Foreign Direct Investments. Polish Journal of Management Studies, Vol. 6., No. 2., 45-54. o.

Soós Károly Attila [2015]: Földrajzi és ágazati koncentráció a cseh, magyar és szlovák exportban. MTA KRTK KTI, Mühelytanulmányok, No. 47.

Stöllinger, R. [2016]: Structural Change and Global Value Chains in the EU. WIIW Working Paper, No. 127.

Szanyi Miklós [2016]: The Emergence of Patronage State in Central Europe The Case of FDI-Related Policies in Hungary. Centre for Economic and Regional Studies HAS Institute of World Economics, Working Paper, No. 222., 30. o. Letölthető: http://www.vki.hu/files/download_993.html

Transparency International Hungary [2014]: Lifting the Lid on Lobbying. Strategic Partnership Agreements in an Uncertain Business and Regulatory Environment. National Report of Hungary. Transparency International Hungary, Budapest. https://transparency.hu/wp-content/ uploads/2016/03/Lifting-the-Lid-on-Lobbying-National-Report-of-Hungary.pdf

van Biesebroeck, J. - Konings, J. - Volpe Martincus, C. [2016]: Did Export Promotion Help Firms Weather the Crisis? Economic Policy, Vol. 31., Issue 88., 653-702. o.

Vlachynsky, M. - Kristály, M. [2017]: Investicné Stimuly. Institute of Economic and Social Studies, Int. 1/2017, Bratislava, 6. o. Letölthetö: http://www.iness.sk/sites/default/files/media/file/pdf/INT/ INT_1-2017_Investicne_stimuly.pdf 